\title{
Prevalence of Hepatitis B Virus Infection Markers among Patients of the Ibn Sina University Hospital Center (Rabat, Morocco)
}

\author{
Mourad Feindiria, ${ }^{a} \quad$ Hakima Kabbaja $^{a}$ Mohammed El Mzibric Bouchra Belkadi ${ }^{\mathrm{b}}$ \\ Najat Bouihat ${ }^{\mathrm{a}}$ Abdelkarim Filali-Maltouf ${ }^{\mathrm{b}}$ Myriam Seffar ${ }^{\mathrm{a}}$ \\ ${ }^{a}$ Central Laboratory of Virology, Ibn Sina University Hospital Center/Faculty of Medicine and Pharmacy of

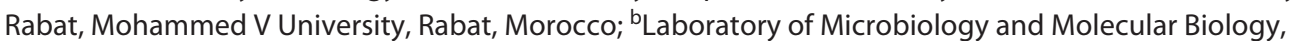 \\ Faculty of Sciences, Mohammed V University, Rabat, Morocco; ${ }^{\circ}$ Medical and Biological Research Unit, \\ The National Center for Energy and Nuclear Science and Technology, Rabat, Morocco
}

\section{Keywords}

Prevalence · Hepatitis B virus · Serological markers ·

Morocco

\begin{abstract}
Introduction: Viral hepatitis B is a global scourge affecting millions of people worldwide. In Morocco, hepatitis B is considered a public health problem, and available data converge to consider Morocco as a country with intermediate endemicity. In the present study, we have planned to evaluate the HBV prevalence in Morocco on a large scale and to assess the prevalence of different serological markers for better management of this infection in Morocco. Methods: This study was conducted on 18,877 patients referring to the Ibn Sina University Hospital Center of Rabat, Morocco. HBV serological markers including $\mathrm{HBsAg}, \mathrm{HBsAb}, \mathrm{HBeAg}, \mathrm{HBe}-$ $A b$, and total $\mathrm{HBCAb}$ were assessed by immune-enzymatic assays. The quantification of HBV DNA was performed by real-time PCR. Results: The overall prevalence of positive cases for $\mathrm{HBsAg}, \mathrm{HBsAb}$, and total $\mathrm{HBcAb}$ was $2.47 \%, 27.66 \%$, and $21.2 \%$, respectively. From 141 patients with an isolated HBcAb serological profile ( $\mathrm{HBcAb}+/ \mathrm{HBsAb}-/ \mathrm{HBsAg}-$ ), HBV DNA was detected in 10 patients, representing a rate of
\end{abstract}

karger@karger.com www.karger.com/int

Karger!

GOPEN ACCESS
(C) 2021 The Author(s)

Published by S. Karger AG, Basel

This is an Open Access article licensed under the Creative Commons Attribution-NonCommercial-4.0 International License (CC BY-NC) (http://www.karger.com/Services/OpenAccessLicense), applicable to the online version of the article only. Usage and distribution for commercial purposes requires written permission.
$7.09 \%$. In the present study, up to $95.78 \%$ of HBV chronic carriers were negative for HBeAg. Conclusion: This study highlights a higher prevalence of $\mathrm{HBsAg}$ in the hospital-based population than the general population reported previously in Morocco and a very low HBV immunization coverage. Of particular interest, detectable HBV DNA levels in isolated HBcAb patients show that exclusive HBsAg screening cannot eliminate the risk of HBV transmission in certain cases. Many efforts are then mandatory to promote serological testing and increase the vaccination rate to limit viral dissemination for better management of this disease in Morocco.

๑) 2021 The Author(s).
Published by S. Karger AG, Basel

\section{Introduction}

Viral hepatitis B is a global scourge affecting nearly 257 million people worldwide. According to the WHO latest estimates, 2 billion people have been infected with hepatitis B virus (HBV) around the world. In 2015, 887,000 people died due to complications caused by HBV infection, notably cirrhosis and hepatocellular carcinoma $[1,2]$.

$\mathrm{HBV}$ is a ubiquitous virus. Chronic carriers, which constitute the reservoir of the virus, are unevenly distrib- 
uted around the world, with Asia being an area with a high prevalence of $\mathrm{HBV}$, as $>8 \%$ of the population are chronic carriers. In Africa, the seroprevalence of HBV infection is variable, ranging from 3 to $20 \%$ [2-4]. HBV is a highly contagious agent; it could be detected in genital secretions, in semen, and at a lower concentration in saliva, breast milk, urine, and tears, but scientific evidence shows that the high concentration of viral particles occurs in the blood of infected subjects [4].

Accordingly, and upon HBV infection, several serological markers are expressed and are of clinical relevance. These markers are also of great interest for epidemiological studies. Indeed, the HBV serological markers discriminate between acute and chronic infections and are used as serologic evidence to evaluate the host immune status. The primary serological markers used in the HBV infection assessment include hepatitis B surface antigen (HBsAg), antibody to hepatitis surface antigen (HBsAb), total antibodies to hepatitis $\mathrm{B}$ core antigen ( $\mathrm{HBcAb})$, and IgM antibody subclass of anti-HBc (IgM HBcAb). Some studies have also introduced other markers like hepatitis $\mathrm{B}$ " $\mathrm{e}$ " antigen (HBeAg) and antibody to hepatitis B " $\mathrm{e}$ " antigen ( $\mathrm{HBeAb})$. These markers, combined together, provide HBV serological patterns that could better complement the clinical evaluation to better manage this infection. More recently, with the introduction of molecular assays in the overall monitoring of infectious diseases, $\mathrm{HBV}$ infection is evaluated by quantitative HBV DNA assessment [5].

In Morocco, due to the absence of a national survey, data are limited to few sporadic studies with a limited number of cases. Before the introduction of the viral hepatitis $B$ vaccine in the extended immunization program in 1999, Morocco was ranked, according to WHO data, among the intermediate prevalence countries for viral hepatitis B [6]. To the best of our knowledge, all studies made in Morocco were conducted on the general population, including blood donors, and no results were reported from a hospital-based study. Thus, the present study was planned to evaluate, on a large scale, the HBV prevalence in Greater Rabat, Morocco, and to assess the prevalence of different serological markers for better management of this infection and related disease in Morocco.

\section{Materials and Methods}

\section{Study Setting}

The study was conducted in the Central Virology Laboratory, referring to Rabat's Ibn Sina University Hospital Center, receiving samples from 10 different hospitals. Patients are mainly from the
Rabat region but also from various cities of the country coming for medical care, surgeries, consultation, tertiary healthcare, etc. Samples were sent to the Virology Lab with a medical prescription to carry out HBV detection, viral load assessment, and virus genotyping, as a part of several diagnoses that will be used by the medical staff for better management of patients' respective diseases. The study was conducted under the local ethical rules, and informed consent was obtained from all patients.

\section{Clinical Specimens}

Specimens were recruited between March 2015 and February 2018. Blood samples have been collected on serum-separating tubes for serological tests and EDTA tubes to quantify HBV DNA by real-time PCR. HBV status was performed without any presumption of hepatitis infection.

\section{HBV Serological Assays}

$\mathrm{HBV}$ serological markers, notably $\mathrm{HBsAg}$, HBeAg, HBsAb, and $\mathrm{HBcAb}$, were detected by Chemiluminescent microparticle immunoassay on the Architect i2000SR analyzer (RRID: SCR_010477; Abbott) according to the manufacturer's recommendations. The results are expressed in international units per milliliter for HBsAb and S/CO ratio for the other markers. An anti-HBs rate of $10 \mathrm{IU} / \mathrm{L}$ was considered protective. The HBeAb were detected by a competitive reaction. HBsAg-positive samples with an S/CO ratio between 1 and 1,000 were confirmed by the neutralization reaction on the Architect i1000SR instrument as recommended by the manufacturer (RRID: SCR_010477; Abbott).

\section{Quantification of $H B V D N A$}

The quantification of HBV DNA was performed by real-time PCR on the Abbott m2000 system (RRID: SCR_010477; Abbott). HBV DNA was extracted from plasma samples by using m2000sp during sample preparation. Quantification of HBV DNA extracted was carried out by using $\mathrm{m} 2000 \mathrm{rt}$. The lower limit of detection was $10 \mathrm{IU} / \mathrm{mL}$. Samples were considered HBV DNA positive if the viral loads are higher than or equal to $10 \mathrm{IU} / \mathrm{mL}$.

\section{Results}

\section{Characteristics of Recruited/HBsAg-Positive Patients}

A total of 18,877 patients were recruited in this study. Overall, $37 \%$ were male, $51 \%$ female, and $12 \%$ children. The average age of patients was 33 (extreme ages: newborn babies to 99 years old). HBV-infected patients came mainly from the hospital of specialties (39.48\%) and Ibn Sina Hospital (35.62\%) (Table 1).

\section{Prevalence of $H B s A g, H B s A b$, and Total $H B c A b$}

Among the recruited patients, 466 patients were HBsAg reactive (53\% males, $41 \%$ females, and $6 \%$ children), representing a prevalence of $2.47 \%$. HBsAb were detected in 5,222 patients (27.66\%) and total HBcAb in 4,002 patients (21.2\%), whereas 12,335 of recruited patients were HBV free (65.34\%). Based on these serological results, pa- 
Table 1. Characteristics of the study population

\begin{tabular}{|c|c|c|c|c|}
\hline \multirow[t]{2}{*}{ Variable } & \multicolumn{2}{|c|}{$\begin{array}{l}\text { Recruited patients } \\
(n=18,877)\end{array}$} & \multicolumn{2}{|c|}{$\begin{array}{l}\text { HBsAg positive } \\
(n=466)\end{array}$} \\
\hline & $n$ & $\%$ & $n$ & $\%$ \\
\hline \multicolumn{5}{|l|}{ Sex } \\
\hline Males & 6,977 & 37 & 247 & 53 \\
\hline Females & 9,697 & 51 & 190 & 41 \\
\hline Children (boys and girls) & 2,203 & 12 & 29 & 6 \\
\hline \multicolumn{5}{|l|}{ Referent hospital } \\
\hline Hospital of specialties & 3,873 & 20.52 & 184 & 39.48 \\
\hline ELAYACHI hospital for orthopedic diseases & 1,421 & 7.53 & 17 & 3.65 \\
\hline Ibn Sina Hospital & 6,072 & 32.17 & 166 & 35.62 \\
\hline Children's hospital & 2,943 & 15.59 & 17 & 3.65 \\
\hline National Reproductive Health Centre & 647 & 3.43 & 12 & 2.58 \\
\hline National Institute of Oncology & 525 & 2.78 & 21 & 4.51 \\
\hline Arrazi hospital for mental diseases & 1,725 & 9.14 & 23 & 4,94 \\
\hline Maternity Souissi & 610 & 3.23 & 7 & 1.50 \\
\hline Moulay Youssef hospital for respiratory diseases & 1,060 & 5.62 & 19 & 4.08 \\
\hline Dental Centre & 1 & 0.01 & 0 & 0 \\
\hline
\end{tabular}

Table 2. Serological profiles of HBV

\begin{tabular}{llllll}
\hline Serological patterns & HBsAg & HBsAb & Total HBcAb & $n$ & $\%$ \\
\hline Susceptible & - & - & - & 12,335 & 65.34 \\
Acute or chronic infection & + & - & + & 450 & 2.38 \\
Immune due to natural infection & - & + & + & 2,666 & 14.12 \\
Immune due to hepatitis B vaccination & - & + & - & 2,540 & 13.46 \\
Isolated HBc antibodies & - & - & + & 870 & 4.61 \\
Ongoing HBsAg/anti-HBs seroconversion & + & + & + & 16 & 0.09 \\
\hline Total & & & & 18,877 & 100 \\
\hline
\end{tabular}

HBV, hepatitis B virus.

tients were classified into 6 serological profiles (Table 1): susceptible, immune due to natural infection, and immune due to hepatitis $B$ vaccination profiles prevailed (Table 2).

\section{$H B V D N A$ in Patients with Isolated $H B c A b$}

In this study, HBV DNA was investigated by qPCR in 141 among the 870 patients with an isolated $\mathrm{HBcAb}$ profile (HBsAg-/HBsAb-/HBcAb+). Overall, $92.91 \%$ of cases had undetectable viral DNA load (131/141). In contrast, 10 patients were HBV DNA positive, and the viral load ranged between 10 and $708 \mathrm{IU} / \mathrm{mL}$, with a median of $34.97 \mathrm{IU} / \mathrm{mL}$ and a mean of $120.86 \pm 213.76 \mathrm{IU} / \mathrm{mL}$.
Prevalence of HBeAg in HBV Chronic Carriers

Among the $466 \mathrm{HBsAg}$-positive cases, 142 were $\mathrm{HBV}$ chronic carriers as they exhibited HBsAg positivity beyond 6 months. HBeAg was detected in only $6 / 142$ cases representing a rate of $4.23 \%$, while their $\mathrm{HBeAb}$ were negative. In contrast, the remaining 136 patients had negative $\mathrm{HBeAg}$ and positive $\mathrm{HBeAb}$ (Table 3). Among them, $70.42 \%(100 / 142)$ had a viral load $<2,000 \mathrm{UI} / \mathrm{mL}$ with a median of $244.39 \mathrm{IU} / \mathrm{mL}$, ranging between 11 and 1,950 $\mathrm{IU} / \mathrm{mL}$ (mean: $498.64 \pm 532.24 \mathrm{IU} / \mathrm{mL}$ ) while the remaining 36 patients had a viral load $>2,000 \mathrm{UI} / \mathrm{mL}$, and the median was $22,159 \mathrm{UI} / \mathrm{mL}$, ranging from 2,120 to $6.24 \pm$ $10^{8} \mathrm{IU} / \mathrm{mL}$ (mean $1.9 \times 10^{7} \pm 1.03 \times 10^{8} \mathrm{UI} / \mathrm{mL}$ ).
82

Intervirology 2022;65:80-86

DOI: $10.1159 / 000518618$
Feindiri/Kabbaj/El Mzibri/Belkadi/ Bouihat/Filali-Maltouf/Seffar 
Table 3. Prevalence of $\mathrm{HBeAg}$ and distribution of HBV DNA levels among HBV chronic carriers

\begin{tabular}{|c|c|c|c|c|c|}
\hline \multirow[t]{2}{*}{ Viral loads, IU/mL } & \multirow[t]{2}{*}{$n$} & \multicolumn{4}{|c|}{ HBe antigen } \\
\hline & & positive & & negative & \\
\hline$<2,000$ & 100 & 0 & $0 \%$ & 100 & $70.42 \%$ \\
\hline$\geq 2,000$ & 42 & 6 & $4.23 \%$ & 36 & $25.35 \%$ \\
\hline Total & 142 & 6 & $4.23 \%$ & 136 & $95.77 \%$ \\
\hline
\end{tabular}

HBV, hepatitis B virus.

\section{Discussion}

Despite the large efforts made to fight against HBV infection, hepatitis is still a major health problem in Morocco. In this study, the prevalence of HBsAg was $2.47 \%$, which is in line with the overall prevalence estimated at $3.3 \%$ by the WHO in the Eastern Mediterranean Region. This HBV seroprevalence consolidates the classification of Morocco as an endemic middle area with a prevalence between 2 and 8\% [7-9]. Previous studies conducted in Morocco on the general population have reported HBV prevalence $<2 \%: 1.66 \%$ among the active population [10] and $1.81 \%$ in the cross-sectional survey enrolling in the large screening program for hepatitis $\mathrm{B}$ and $\mathrm{C}$ conducted by the Pasteur Institute of Morocco [11]. Other studies conducted on blood donors in Rabat in 2013 and 2016 have reported the prevalence of 0.8 and $1.34 \%$, respectively [12, 13], suggesting a slight difference in HBsAg prevalence between our recruited patients and the general populations as reported previously.

Overall, only $27.66 \%$ of patients were positive for HB$\mathrm{sAb}$. This antibody screening is carried out to follow the evolution of hepatitis B to check $\mathrm{HBs} A g / \mathrm{HBsAb}$ seroconversion status, but also with the aim of evaluating the effectiveness of HBV vaccination. This value remains very low given the development achieved in Morocco in terms of immunization coverage since 1999 [14]. Of particular interest, a significant portion of patients recruited for this study are at high risk of contracting HBV as they are likely to receive massive and/or iterative transfusions (hemophiliacs, dialysis, renal failure, and organ transplant candidates), in psychiatric institutions, hospitalized patients, etc. The double burden due to sur-infection with HBV could be fatal for these vulnerable patients. Therefore, vaccination is still the fundamental cornerstone to fight against $\mathrm{HBV}$, as it prevents chronic B viral hepatitis in $95 \%$ of cases and limits the occurrence of hepatocellular carcinoma [15]. In Morocco, anti-HBV vaccination had started in the 2000s, and vaccination coverage for children under 1 year has increased from 33\% in 2000 to $93 \%$ in 2005 [14]; therefore, we can easily assume that in the upcoming years, most adults will be vaccinated leading to a significant decrease in HBV-positive cases. Total HBcAb were found in $21.2 \%$ of patients. These antibody compounds are IgM $\mathrm{HBcAb}$ and IgG $\mathrm{HBcAb}$, which are widely reported as a good indicator of the HBV endemic status. A lower prevalence of total $\mathrm{HBcAb}$ was founded in low-prevalence countries such as Iran, France, and Spain $(4.9 \%, 7.3 \%$, and $8.2 \%$, respectively) [16-18]. In contrast, a higher prevalence was found in high-prevalence countries like Nigeria, Togo, and Mauritania (32\%, 53.9\%, and 76.5\%, respectively) [19-21].

Assessment of HBsAg, HBsAb, and total HBcAb serological markers of HBV is of great interest in hepatitis management as they allow the identification of different phases of HBV infection as well as monitoring of patients infected by HBV. The other virological markers, notably IgM $\mathrm{HBcAb}, \mathrm{HBeAg}, \mathrm{HBe} A b$, quantitative HBsAg, and molecular HBV DNA quantification, are widely used but depend on the initial results of the first 3 markers. Ultimately, and according to the obtained results, the patients had 6 distinct serological profiles (Table 2).

The great majority of patients has never been in contact with the HBV $(65,34 \%)$; HBsAg-positive patients ( $\mathrm{HBs} \mathrm{Ag}+/ \mathrm{HBsAb}-/ \mathrm{HBcAb}+$ ) represent $2.38 \%$ of total recruited patients, and this serological profile is referring to an ongoing HBV infection (acute or chronic). Chronically infected patients are characterized by the persistence of HBsAg beyond 6 months and the loss of IgM HBcAb, while the acute infection is distinguished by positive IgM $\mathrm{HBcAb}$ or by the absence of detectable total $\mathrm{HBcAb}$ in the case of recent infection. Another atypical serological profile was found with a very low rate $(0.09 \%)$, and it is characterized by the positivity of the 3 serological markers $(\mathrm{HBsAg}+/ \mathrm{HBs} \mathrm{Ab}+/ \mathrm{HBcAb}+)$. This situation usually indicates ongoing $\mathrm{HBs} \mathrm{Ag} / \mathrm{HBs} \mathrm{Ab}$ seroconversion but does not exclude chronic infection with simultaneous detection of HBsAg and HBsAb. This serological profile can be explained by the emergence of HBV escape mutants not 
recognized by the circulating $\mathrm{HBs} A \mathrm{~b}$ directed against the wild-type viruses or by the presence of heterologous subtype-specific antibodies directed against HBsAg subtypes different from the coexisting HBsAg [22]. Patients immunized by $\mathrm{HBV}$ infection ( $\mathrm{HBs} \mathrm{Ag}-/ \mathrm{HBs} \mathrm{Ab}+/ \mathrm{HBcAb}+$ ) represent a rate of $14.12 \%$. This serological profile characterizes patients formerly infected, recovered, and immunized against $\mathrm{HBV}$. Last, immunized patients by vaccination ( $\mathrm{HBs} \mathrm{Ag}-/ \mathrm{HBs} \mathrm{Ab}+/ \mathrm{HBcAb}-)$ were present with a proportion of $13.46 \%$.

An isolated $\mathrm{HBcAb}$ serological profile ( $\mathrm{HBsAg}-/ \mathrm{HB}-$ $\mathrm{sAb}-/ \mathrm{HBcAb}+$ ) was observed in $4.61 \%$ of recruited patients. These antibodies are normally associated with $\mathrm{HB}$ sAg during acute and chronic hepatitis B or HBsAb after $\mathrm{HBsAg} /$ anti-HBs seroconversion. This serological profile could be explained by [23-25] the following: (1) the loss of $\mathrm{HBsAb}$ after the resolution of HBV infection; indeed, the disappearance of $\mathrm{HBsAb}$ may occur several years after $\mathrm{HBsAg}$ /anti-HBs seroconversion, while $\mathrm{HBcAb}$ persist throughout life; the persistence of these antibodies is probably due to their high level of immunogenicity [26]; (2) acute hepatitis B during the so-called acute window period before the appearance of $\mathrm{HBsAb}$; (3) false-positive reactivity for total $\mathrm{HBcAb}$; (4) this serological profile may also correspond to occult B viral hepatitis. In this study, HBV DNA was detected in $7.09 \%$ of patients with isolated $\mathrm{HBcAb}$. The absence of detectable HBsAg in the serum of these patients is probably due to the production of an antigenically modified $S$ protein (mutants $S$ ) and therefore not detected by conventional serological tests [25]. In several studies, detection of HBV DNA in serum "HBcAb isolated" has been reported in several studies, notably in Tunisia, Lebanon, and Egypt with a prevalence of $4.47 \%, 13 \%$, and $17.2 \%$, respectively [23, 27, 28]. According to the literature, the occurrence of detectable HBV DNA among patients with an "isolated HBcAb" serological profile becomes higher when they are co-infected with HCV and/or HIV $[29,30]$. In this regard, this serological profile should be monitored closely as it may entail the HBV transmission, especially in patients receiving blood transfusions or organ transplants.

In this study, only $4.23 \%$ of HBV chronic carriers were HBeAg positive. These results are in agreement with those reported in other African countries, including Cameroon where a survey conducted in 3 hospitals in Yaoundé showed that $92 \%$ of the chronic carriers of hepatitis $B$ were negative for $\mathrm{HBeAg}$ [31]. Scientific evidence showed that quantification of HBV DNA in patients with chronic $\mathrm{HBV}$ infection and negative $\mathrm{HBeAg}$ is of great interest in hepatitis management as it leads to differentia- tion between 2 phases of chronic hepatitis B. Patients with low HBV DNA load $(<2,000 \mathrm{IU} / \mathrm{mL})$ correspond to $\mathrm{HBeAg}$-negative chronic HBV infection (formerly known as inactive carrier phase) that may allow the resolution of hepatitis B (HBsAg/anti-HBs seroconversion) or reactivation episodes, while patients with a high viral load $(\geq 20,00 \mathrm{IU} / \mathrm{mL})$ match with $\mathrm{HBeAg}$-negative chronic hepatitis $B$ phase and are most likely to carry HBV variants [32]. HBeAg-negative chronic hepatitis B is frequently observed in patients in sub-Saharan Africa, the Middle East, and the Mediterranean basin. Several studies reported that this form progresses gradually and has become the dominant form of chronic $\mathrm{B}$ hepatitis around the world. An increase in the rate of negative HBeAg patients in the USA and countries of Europe and Asia is reported [33]. Of particular interest, HBeAg-negative chronic hepatitis B is widely reported to be associated with the development of severe liver disease [32, 34-36]. Undetectable level of $\mathrm{HBeAg}$ in chronic hepatitis B patients was reported to be a result of 2 major mutations: pre-core mutation characterized by the substitution of guanine (TGG) by adenine (TAG) in position 1,896 , resulting in premature cessation of protein synthesis, and the double mutation of PBC (A1762T and G1764A) responsible for a significant decrease in the expression of HBe protein. These mutant forms allow the virus to better resist the pressure of the host immune system [37].

Moreover, many previous studies have reported that pre-core mutation is one of the main causes of the negativity of $\mathrm{HBeAg}$ in chronic hepatitis B patients. Of particular interest, these studies reveal the predominance of genotype $\mathrm{D}$ among their patients $[34,38,39]$. Indeed, precore mutation (G1896A) helps to stabilize the stem-loop of pre-genome RNA by strengthening the pairing with thymine located in position 1,858 in genotypes $\mathrm{B}, \mathrm{D}, \mathrm{E}$, and $\mathrm{C}$ in contrast to genotypes $\mathrm{A}, \mathrm{F}$, and $\mathrm{H}$ harboring a cytosine in position 1,858 and requiring a second mutation $(\mathrm{C} 1858 \mathrm{~T})$ to stabilize the pre-genome RNA $[37,40]$.

In Morocco, recent studies among patients with chronic hepatitis B reported the predominance of genotype D with percentages varying between 87.6 and $100 \%$. These results could explain the high prevalence of HBeAg-negative patients found in this study [39, 41-43]. Hence, a close follow-up is needed for better management of these patients.

The present study is very informative and has many strengths, namely, the huge number of recruited cases and the evaluation of HBV status based on a considerable number of virological biomarkers. However, the main limitation of the study is the nonrepresentativeness of re-
Feindiri/Kabbaj/El Mzibri/Belkadi/ Bouihat/Filali-Maltouf/Seffar 
cruited cases. In fact, our patients are mainly from Rabat's region which is not representative of the Moroccan population. Even more, data at the subnational level are also required to estimate disease burden and guide health and vaccine policy. Hence, additional studies on a large and representative population are needed to evaluate more accurately the national prevalence of hepatitis B.

\section{Conclusion}

This study clearly highlighted a high level of HBV prevalence in Morocco and a very low HBV immunization coverage. HBV infection is still a public health problem, and new recommendations, in accordance with WHO guidelines, should be set to promote serological testing and reinforce the vaccination protocol to limit viral dissemination and ensure better management of this disease in Morocco.

\section{Statement of Ethics}

This study was conducted in the Virology Lab of the Ibn Sina University Hospital Center which is a central and a referent lab receiving samples for all the public hospitals in Rabat, Morocco. All samples were sent with a medical prescription to carry out $\mathrm{HBV}$ detection, viral load assessment, and virus genotyping, and all patients provided their written and informed consent for this test and have agreed to do these analyses. Moreover, all these analyses were done for hepatitis diagnosis, and therefore we did not seek ethical approval to use these samples for research purposes and was not required for this study in accordance with local/national guidelines. The publication of these results was approved by the Scientific Board of the Central Virology Lab.

\section{Conflict of Interest Statement}

The authors have no conflicts of interest to declare.

\section{Funding Sources}

Our study did not require any source of funding.

\section{Author Contributions}

M.F. participated in the project design, experimental analysis, and statistical analysis and drafted the manuscript; H.K. contributed to the interpretation of the results; M.E.M. provided critical feedback and data analysis and reviewed the final manuscript; B.B. participated in data analysis and review of the final manuscript; N.B. participated in the experimental analysis; A.F.-M. participated in the design of the project and review of the final manuscript; M.S. participated in the design and coordination of the project and review of the final manuscript.

\section{Data Availability Statement}

All data generated or analyzed during this study are included in this article. Further inquiries can be directed to the corresponding author.

\section{References}

1 Lavanchy D. Hepatitis B virus epidemiology, disease burden, treatment, and current and emerging prevention and control measures. J Viral Hepat. 2004;11(2):97-107.

2 World Health Organization. Hepatitis B. 2020 [cited 2021 Jan 5]. Available from: https: //www.who.int/news-room/fact-sheets/detail/hepatitis-b.

3 MacLachlan JH, Cowie BC. Hepatitis B virus epidemiology. Cold Spring Harb Perspect Med. 2015;5(5):a021410.

4 World Health Organization. Introduction of hepatitis B vaccine into childhood immunization services: management guidelines, including information for health workers and parents. No. WHO/V\&B/01.31. 2001.

5 Pawlotsky J-M. Les techniques virologiques de diagnostic et de suivi de l'hépatite B. Gastroentérologie Clinique et Biologique. 2008; 32(1):S56-63.
6 Previsani N, Lavanchy D. WHO/CDS/CSR/ LYO/2002.2: Hepatitis B. Geneva: World Health Organization; 2002.

7 Schweitzer A, Horn J, Mikolajczyk RT, Krause G, Ott JJ. Estimations of worldwide Prevalence of chronic hepatitis B virus infection: a systematic review of data published between 1965 and 2013. Lancet. 2015;386(10003):1546-55.

8 André F. Hepatitis B epidemiology in Asia, the Middle East and Africa. Vaccine. 2000;18 Suppl 1(1):S20-2.

9 Ott JJ, Stevens GA, Groeger J, Wiersma ST Global epidemiology of hepatitis B virus infection: new estimates of age-specific $\mathrm{HBsAg}$ seroprevalence and endemicity. Vaccine. 2012;30(12):2212-9.

10 Sbai A, Baha W, Ougabrai H, Allalia T, Dersi $\mathrm{N}$, Lazaar F, et al. Prévalence de l'infection par le virus de l'hépatite $B$ et l'évaluation des facteurs de risque au Maroc. Pathologie Biologie. 2012;60(5):e65-9.
11 Baha W, Foullous A, Dersi N, They-they TP, El alaoui K, Nourichafi N, et al. Prevalence and risk factors of hepatitis $\mathrm{B}$ and $\mathrm{C}$ virus infections among the general population and blood donors in Morocco. BMC Public Health. 2013;13(1):50-8.

12 Adouani B, Alami R, Laouina A, Bouhlal N, Benahadi A, Boulahdid S, et al. Hépatite B chez la population des donneurs de sang au Maroc: comparaison de la prévalence de l'Ag HBs chez les différentes catégories de donneurs. Transfus Clin Biol. 2013;3(20):305-6.

13 Laouina A, Adouani B, Alami R, Abouyoub A, Hajjout K, Benajiba M. Prévalence des marqueurs infectieux transmissibles par transfusion chez les donneurs de sang au CRTS de Rabat (Maroc). Transf Clin Biol. 2016;23(4):309-10.

14 Barkat A, Braikat M, Lamdouar Bouazzaoui N. Calendrier National de Vaccination: évolution et perspectives. 2008. 
15 Launay $\mathrm{O}$, Floret D. Vaccination contre l'hépatite B. Med Sci. 2015;31(5):551-8.

16 Karimi G, Zadsar M, Vafaei N, Sharifi Z, FalahTafti M. Prevalence of antibody to Hepatitis $B$ core antigen and Hepatitis $B$ virus DNA in HBsAg negative healthy blood donors. Virol J. 2016;13(1):36-6.

17 Antona D, Larsen C. Épidémiologie de l'hépatite B en France. Virologie. 2010;14(1): 23-34.

18 Cuadrado A, Perelló C, Cabezas J, Llerena S, Llop E, Escudero MD, et al. Update on epidemiology of hepatitis B in a low-endemic European country: there is still much to do. J Viral Hepat. 2020;27(11):1261-5.

19 Ogunfemi MK, Olawumi HO, Olokoba AB, Kagu MB, Biliaminu SA, Durowade KA, et al. Prevalence of antibody to hepatitis $B$ core antigen among hepatitis B surface antigen-negative blood donors in Ilorin, Nigeria: A CrossSectional Study. Malawi Med J. 2017;29(1): 32-6.

20 Têko M, Dorkenoo M, Agbenu E, Abudu A Bonou K, Ameyissa A, et al. Seroprevalence des anticorps anti-HBc chez les donneurs de sang de Lome (Togo). Journal de la Recherche Scientifique de l'Université de Lomé. 2016; 18(2):187-92.

21 Mansour W, Malick FZ, Sidiya A, Ishagh E, Chekaraou MA, Veillon P, et al. Prevalence, risk factors, and molecular epidemiology of hepatitis B and hepatitis delta virus in pregnant women and in patients in Mauritania. J Med Virol. 2012;84(8):1186-98.

22 Pondé RA. The underlying mechanisms for the "simultaneous HBsAg and anti-HBs serological profile”. Eur J Clin Microbiol Infect Dis. 2011;30(11):1325-40.

23 Berrajah-Fki L, Halima SB, Guermazi F, Hammami A, Karray-Hakim H. Signification du profil sérologique anticorps anti-HBC isolés chez 284 patients suspects d'être infectés par le virus de l'hépatite $\mathrm{B}$. Ann Biol Clin. 2006;64(5):451-5.

24 Jeanblanc G. Stratégies de dépistage biologique des hépatites virales $\mathrm{B}$ et $\mathrm{C}$. France: HAS Service Évaluation Économique Santé Publique; 2011.
25 Wang Q, Klenerman P, Semmo N. Significance of anti-HBc alone serological status in clinical practice. Lancet Gastroenterol Hepatol. 2017;2(2):123-34.

26 Milich DR, Chen M, Schödel F, Peterson DL, Jones JE, Hughes JL. Role of B cells in antigen presentation of the hepatitis B core. Proc Natl Acad Sci U S A. 1997;94(26):14648-53.

27 Ramia S, Ramlawi F, Kanaan M, Klayme S, Naman R. Frequency and significance of antibodies against hepatitis B core (anti-HBc) antigen as the only serological marker for hepatitis B infection in Lebanese blood donors. Epidemiol Infect. 2005;133(4):695-9.

28 Said ZN, Sayed MH, Salama II, Aboel-Magd EK, Mahmoud MH, Setouhy ME, et al. Occult hepatitis B virus infection among Egyptian blood donors. World J Hepatol. 2013;5(2): 64-73.

29 Colomina-Rodríguez J, González-García D, Burgos-Teruel A, Fernández-Lorenz N, Guerrero-Espejo A. Significance of hepatitis $\mathrm{B}$ core antibody as the only marker of hepatitis B infection. Enferm Infecc Microbiol Clin. 2005;23(2):80-5.

30 Jain M, Chakravarti A, Kar P. Clinical significance of isolated anti- $\mathrm{HBc}$ positivity in cases of chronic liver disease in New Delhi, India. J Glob Infect Dis. 2009;1(1):29-32.

31 Ankouane F, Kowo M, Njoya O, Sida MB, Tzeuton C, Ndam ECN. Hépatite B chronique à antigène hbe négatif à yaoundé, cameroun. Health Sci Dis. 2015;16(3):1-5.

32 European Association for the Study of the Liver. EASL 2017 clinical practice guidelines on the management of hepatitis B virus infection. J Hepatol. 2017;67(2):370-98.

33 Funk ML, Rosenberg DM, Lok AS. Worldwide epidemiology of HBeAg-negative chronic hepatitis $\mathrm{B}$ and associated precore and core promoter variants. J Viral Hepat. 2002;9(1):52-61.

34 Rezende RE, Fonseca BA, Ramalho LN, Zucoloto S, Pinho JR, Bertolini DA, et al. The precore mutation is associated with severity of liver damage in Brazilian patients with chronic hepatitis B. J Clin Virol. 2005;32(1):53-9.
35 Croagh CM, Bell SJ, Slavin J, Kong YX, Chen RY, Locarnini S, et al. Increasing hepatitis B viral load is associated with risk of significant liver fibrosis in $\mathrm{HBeAg-negative} \mathrm{but} \mathrm{not}$ HBeAg-positive chronic hepatitis B. Liver Int. 2010;30(8):1115-22.

36 Zarski JP, Marcellin P, Leroy V, Trepo C, Samuel D, Ganne-Carrie N, et al. Characteristics of patients with chronic hepatitis B in France: predominant frequency of $\mathrm{HBe}$ antigen negative cases. J Hepatol. 2006;45(3): 355-60.

37 Ducancelle A, Pivert A, Lunel-Fabiani F. Les mutants précore et du promoteur basal du core du virus de l'hépatite B. Virologie. 2011; 15(2):100-14.

38 Ayed K, Gorgi Y, Ayed-Jendoubi S, Aouadi H, Sfar I, Najjar T, et al. Hepatitis B virus genotypes and precore/core-promoter mutations in Tunisian patients with chronic hepatitis B virus infection. J Infect. 2007;54(3):291-7.

39 Kitab B, Essaid El Feydi A, Afifi R, Trepo C, Benazzouz M, Essamri W, et al. Variability in the precore and core promoter regions of HBV strains in Morocco: characterization and impact on liver disease progression. PLoS One. 2012;7(8):e42891.

40 Lok AS, Akarca U, Greene S. Mutations in the pre-core region of hepatitis $B$ virus serve to enhance the stability of the secondary structure of the pre-genome encapsidation signal. Proc Natl Acad Sci U S A. 1994;91(9):407781.

41 Ezzikouri S, Chemin I, Chafik A, Wakrim L, Nourlil J, Malki AE, et al. Genotype determination in Moroccan hepatitis B chronic carriers. Infect Genet Evol. 2008;8(3):306-12.

42 Kitab B, El Feydi AE, Afifi R, Derdabi O, Cherradi Y, Benazzouz M, et al. Hepatitis B genotypes/subgenotypes and MHR variants among Moroccan chronic carriers. J infect. 2011;63(1):66-75.

43 Baha W, Ennaji MM, Lazar F, Melloul M, El Fahime E, El Malki A, et al. HBV genotypes prevalence, precore and basal core mutants in Morocco. Infect Genet Evol. 2012;12(6): 1157-62. 